\title{
E-Government for Construction: The Case of Singapore's CORENET Project
}

\author{
Bee-Hua Goh \\ Department of Building, School of Design and Environment, National University of Singapore, \\ Singapore bdggohbh@nus.edu.sg
}

\begin{abstract}
In 1999, the Singapore Government envisioned a need to transform the construction industry through the Construction 21 Blueprint by a strategic vision. In line with the broader plan to develop Singapore into a knowledgedriven economy, this industry aspires to become 'a World Class Builder in the Knowledge Age'. And earlier, as part of the IT 2000 master plan for Singapore, the Construction Real Estate Network (CORENET) project has been set up in July 1993 to serve as a major information technology (IT) initiative. The goal of CORENET is to "re-engineer the business processes of the construction industry to achieve a quantum leap in turnaround time, productivity and quality." Specifically, its efforts are targeted at developing a set of infrastructure and industry projects, involving various government agencies and other industry players, to meet this goal. On the infrastructure projects, one thrust looks at providing Government to Business infrastructure to facilitate electronic building plans submission, checking and approval processes. Applying the concept of process re-engineering through the adoption of IT to the traditional building plans submission, checking and approval processes, the CORENET has now an infrastructure for: (i) One-stop Submission (OSSC) of building plans for approval; (ii) Buildable Design Appraisal (eBDAS); and (iii) Integrated Building Plan (IBP) and Integrated Building Services Plan (IBS) checking. The prevailing success and benefits of the three implemented projects are examined and discussed in relation to their re-engineered IT-enabled processes as well as feedback from a survey of the industry.
\end{abstract}

Keywords: Business process reengineering, Inter-Enterprise interoperation, Strategic business transformation, Work flow model

\section{SINGAPORE'S CORENET}

In January 1991, the National Computer Board (now IDA) initiated the IT 2000 study to examine how IT can create new competitive advantages and enhance the quality of life in Singapore. As such, the study group known as CORENET (Construction and Real Estate NETwork) was set up in July 1993. Since then, CORENET has come a long way to become a major IT initiative led by the Ministry of National Development and driven by the Building and Construction Authority (BCA) in collaboration with other public and private organizations. The goal of CORENET is to "re-engineer the business processes of the construction industry to achieve a quantum leap in turnaround time, productivity and quality." In order to

Please use the following format when citing this chapter:

Goh, B.-H., 2007, in IFIP International Federation for Information Processing, Volume 254, Research and Practical Issues of Enterprise Information Systems II Volume 1, eds. L. Xu. Tjoa A., Chaudhry S. (Boston: Springer), pp. $327-$ 336. 
achieve this, CORENET revolves around developing IT systems and key infrastructure to integrate the four major processes of a building project life cycle. Broadly, the effort is focused on developing a set of infrastructure and industry projects in order to:

i) provide Information Services to allow businesses to speed up business planning and decision making processes;

ii) provide Government to Business infrastructure to facilitate electronic building plans submission, checking and approval processes;

iii) provide Business to Business enablers to facilitate building project collaborations and business transactions;

iv) provide a set of standards to improve business communications; and

v) provide a series of promotional, training and incentive programmes to create awareness and encourage adoption.

The key Government to Business infrastructure projects completed to date is the One-Stop Submission Centre (OSSC), the Electronic Buildable Design Appraisal System (eBDAS) and the Integrated Building Plan and Building Service Plan Checking System (IBP/IBS). Other infrastructure projects to be developed include the Enterprise Content Management System (ECMS), the Integrated Structural Plan Checking System (ISP) and the Design Objects Library (DOL).

\section{AIM OF THE PAPER}

The paper aims to describe the Government to Business infrastructure projects developed and implemented in Singapore through a discussion of their benefits derived from the re-engineered IT-enabled processes as well as the feedback obtained from a survey of the users of the new IT infrastructure.

\section{THE TRADITIONAL BUILDING DESIGN PROCESS}

Traditionally, the whole construction process comprises four distinct sequential stages. They are design, tender documentation and selection, construction, and handover and maintenance. In the first stage, the key activities of design consist of developing concept and schematic designs, and obtaining planning approvals. As planning approvals are granted by the various regulatory bodies, the building owner through the appointed design consultant (or the Qualified Person) needs to submit the building plans to these bodies separately to apply for the approvals. The complex process of submitting the application, checking against planning requirements, evaluating the proposal, re-submission for non-compliance and issuing approval 
involves many parties and uses different channels of communication. The workflow for building plan submission in Singapore is depicted in Figure 1.

\section{WORK,FLW FOR BUEDIMG PLAW SUBBASSIOY}

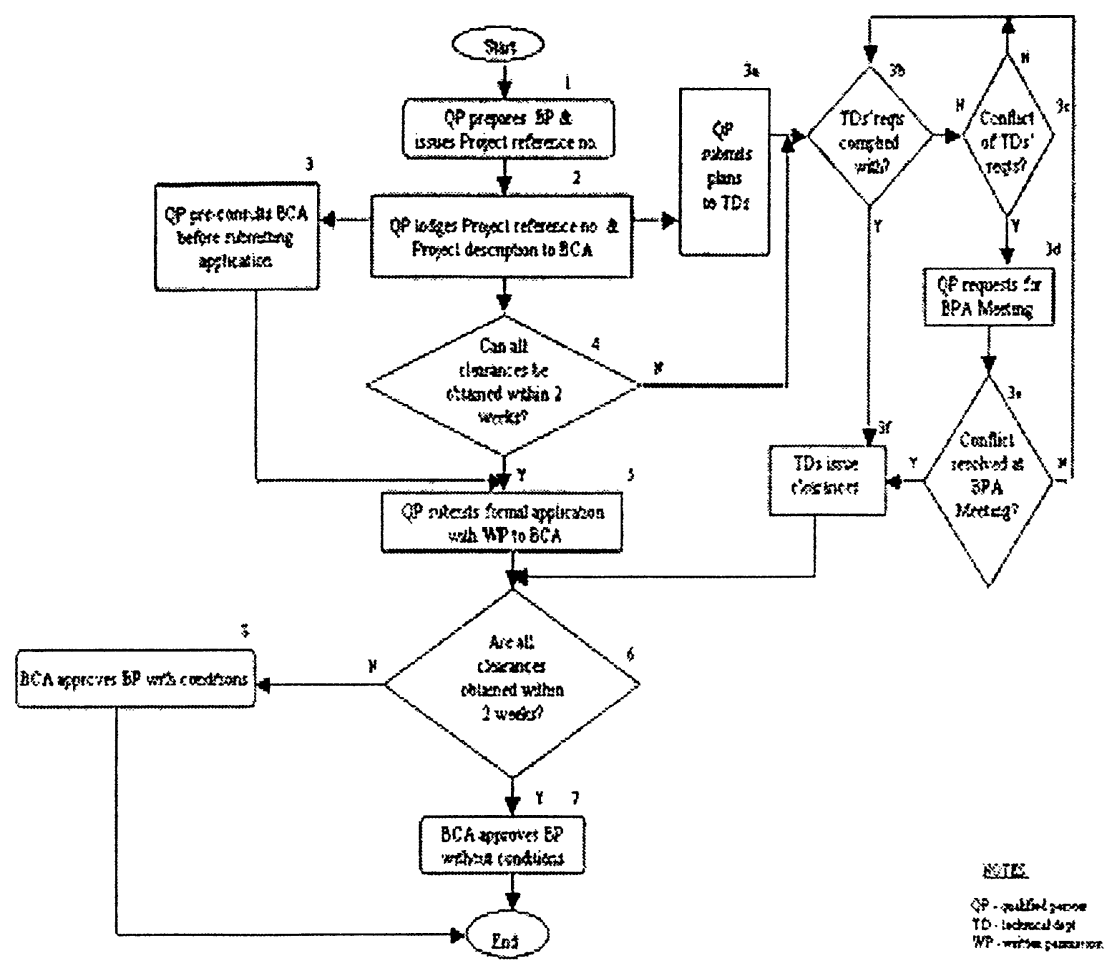

Figure 1. Workflow for Building Plan Submission in Singapore (Source: [5])

During the design stage, consultants in Singapore have to take into consideration, among other regulations, compliance with a regulation pertaining to buildable design. Under the Building Control Act, the regulation on buildable design was introduced in 2001 to improve the efficiency and standardisation of designs, processes, construction techniques, products and materials. In order to reduce the number of workers on site and achieve better site productivity, the industry has to adopt more labour efficient designs and use pre-assembled products. Hence, the regulation requires building designs to have a minimum buildability score as compliance. The Buildable Design Appraisal System (BDAS) was developed by the $\mathrm{BCA}$ as a scoring system to measure the potential impact of a building design on the usage of labour. The buildability score formula is based on the design of three components which are the structural system, wall system and other buildable design features. 


\section{APPLYING PROCESS RE-ENGINEERING TO THE TRADITIONAL BUILDING PLAN APPROVAL ACTIVITIES}

In order to examine the benefits derivable from the completed Government to Business infrastructure projects, namely OSSC, eBDAS and IBP/IBS, there is a need to look at the traditional process and compare it with the re-engineered process that is enabled by IT. According to Hammer and Champy [1], technology enables the processes that are the essence of re-engineering to be re-designed. As they have explained in simple terms, without re-engineering, IT delivers little payoff; without IT, little re-engineering can be done.

In Table 1, a brief description of each of the systems is given, followed by the main elements of the re-engineered process that are enabled by IT. In addition, the traditional process for each of the building plan approval activities is explained for the purpose of highlighting the benefits to be derived from using each of the developed systems.

Table 1. Process Re-engineering Applied to Building Plan Approval (See details: [6])

\begin{tabular}{|c|c|c|}
\hline Type of Project & Re-engineered Process & Traditional Process \\
\hline $\begin{array}{l}\text { OSSC } \\
\text { Provides a network } \\
\text { infrastructure that supports } \\
\text { electronic submission of } \\
\text { building project documents } \\
\text { to regulatory agencies for } \\
\text { processing and approval } \\
\text { through a secure } \\
\text { environment. }\end{array}$ & $\begin{array}{l}\text { OSSC provides a virtual one-stop } \\
\text { round the clock 'counter' to } \\
\text { facilitate: } \\
\text { - electronic submission to } \\
\text { multiple regulatory agencies; } \\
\text { on-line enquiry of submission } \\
\text { status; } \\
\text { integration of application forms } \\
\text { and fee collection; } \\
\text { faster processing and } \\
\text { turnaround time; and } \\
\text { elimination of printing of plans } \\
\text { and forms. }\end{array}$ & $\begin{array}{l}\text { A 'Qualified Person' } \\
\text { makes multiple } \\
\text { submissions resulting in } \\
\text { time and money wasted for } \\
\text { multiple trips. There is: } \\
\text { - voluminous paper } \\
\text { documents; } \\
\text { manual processing of } \\
\text { submission and } \\
\text { building plans; } \\
\text { insufficient physical } \\
\text { storage space; and } \\
\text { inefficient exchange of } \\
\text { project information and } \\
\text { coordination of project } \\
\text { team members. }\end{array}$ \\
\hline $\begin{array}{l}\text { eBDAS } \\
\text { It is an electronic module } \\
\text { to compute the buildability } \\
\text { score and check compliance } \\
\text { of building plans with the } \\
\text { "Code of Practice on } \\
\text { Buildable Design". }\end{array}$ & $\begin{array}{l}\text { The developed system is an } \\
\text { electronic geometric-based } \\
\text { Buildable Design Appraisal System } \\
\text { as part of the BDAS legislation } \\
\text { exercise to provide both the } \\
\text { 'Qualified Person' and BCA officer } \\
\text { an electronic tool to assist them in } \\
\text { the preparation, measurement, } \\
\text { consolidation, reporting, verification } \\
\text { and analysis of buildability scores. }\end{array}$ & $\begin{array}{l}\text { On most occasions, the } \\
\text { 'Qualified Person' and } \\
\text { BCA officers need to } \\
\text { perform manual quantity } \\
\text { taking-off from hardcopies } \\
\text { of computer-aided design } \\
\text { (CAD) files in order to } \\
\text { compute the buildability } \\
\text { score according to the } \\
\text { BDAS requirements. } \\
\text { - This computational } \\
\text { process can be time } \\
\text { consuming. }\end{array}$ \\
\hline
\end{tabular}




\begin{tabular}{|c|c|c|}
\hline $\begin{array}{l}\text { IBP/IBS } \\
\text { It is an artificial } \\
\text { intelligence checking system } \\
\text { that automatically checks } \\
\text { electronic plans for } \\
\text { compliance with regulatory } \\
\text { requirements. }\end{array}$ & $\begin{array}{l}\text { The IBP/IBS system provides an } \\
\text { expert tool to enhance overall } \\
\text { effectiveness and efficiency of } \\
\text { building plan and building services } \\
\text { approval process. } \\
\text { There is a consistent way of } \\
\text { interpretation of regulatory } \\
\text { codes and regulations. } \\
\text { It serves the purpose of a } \\
\text { 'Qualified Person' with self- } \\
\text { checking capabilities to aid in } \\
\text { the design process prior to } \\
\text { submission for approval. }\end{array}$ & $\begin{array}{l}\text { The plan checking is } \\
\text { manually performed by } \\
\text { experienced staff. } \\
\text { - Staff will require in- } \\
\text { depth knowledge of } \\
\text { codes and } \\
\text { regulations. } \\
\text { Interpretation of } \\
\text { clauses may differ } \\
\text { from individual to } \\
\text { individual. }\end{array}$ \\
\hline
\end{tabular}

\section{INDUSTRY FEEDBACK ON THE DEVELOPED INFRASTRUCTURE PROJECTS}

A mailed questionnaire survey was conducted in 2003 to solicit views of industry players on the benefits that had been derived by using the new IT infrastructures. A total of 754 companies operating in the construction industry in the areas of architecture, engineering, quantity surveying, property development, construction, and product manufacturing and supplies had been sent a copy of the questionnaire. A breakdown of the sampling population and the rate of response by category are shown in Tables 2 and 3. Responses from the survey were analyzed using the SPSS software version 11.0. Missing data or incomplete entry for each question has been excluded from the analysis of total response.

Table 2. A Breakdown of the Sampling Population, in Number and Percent

\begin{tabular}{|c|c|c|}
\hline Category & No. of Companies & Per cent \\
\hline Architecture & 361 & 47.9 \\
\hline Engineering & 131 & 17.4 \\
\hline Quantity Surveying & 19 & 2.5 \\
\hline Property Development & 23 & 3.0 \\
\hline Construction & 129 & 17.1 \\
\hline $\begin{array}{c}\text { Product Manufacturing } \\
\text { and Supplies }\end{array}$ & 91 & 12.1 \\
\hline Total: & 754 & $\mathbf{1 0 0 . 0}$ \\
\hline
\end{tabular}


Table 3. The Rate of Response for the Survey, in Number and Percent

\begin{tabular}{|c|c|c|c|}
\hline Category & $\begin{array}{c}\text { No. of } \\
\text { Targeted } \\
\text { Companies }\end{array}$ & $\begin{array}{c}\text { No. of } \\
\text { Respondent } \\
\text { Companies }\end{array}$ & $\begin{array}{c}\text { Per cent of } \\
\text { Respondent } \\
\text { Companies }\end{array}$ \\
\hline Architecture & 361 & 38 & 10.5 \\
\hline Engineering & 131 & 15 & 11.5 \\
\hline Quantity Surveying & 19 & 5 & 26.3 \\
\hline Property Development & 23 & 2 & 8.7 \\
\hline Construction & 129 & 10 & 7.8 \\
\hline $\begin{array}{c}\text { Product } \\
\text { Manufacturing/Supplying }\end{array}$ & 91 & 1 & 1.1 \\
\hline Multi-disciplinary & - & 13 & N.A. \\
\hline Total: & 754 & 84 & 11.1 \\
\hline
\end{tabular}

Among the list of 39 questions, two questions (Questions 38 and 39) have been dedicated to soliciting feedback on the speed of implementation of the CORENET projects and whether benefits had been derived by the users, and whether the amount of promotion and training provided by the BCA was sufficient so as to equip industry players with skills to use these IT infrastructures. The actual questions are shown in Figure 2.

38. How would you assess the following aspects of the CORENET projects?

Speed of Implementation (Please circle: 1 for 'too slow' and 5 for 'too fast'.):

a. Information standardisation

- CAD standards (CP83). 
- Cost Classification (CP80)................. 2 2 $3 \quad 4 \quad 5$

- Resources Classification (CP93)...........1 $2 \quad 3 \quad 4 \quad 4 \quad 5$

- Electronic Measurement standard $\ldots \ldots \ldots \ldots 1 \quad 2 \quad 3 \quad 4 \quad 4 \quad 5$

b. One-Stop Submission $\ldots \ldots \ldots \ldots \ldots \ldots \ldots \ldots 14 \ldots \ldots \ldots$

c. Electronic Buildable Design Appraisal System

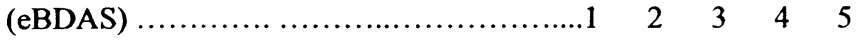

d. e-Collaboration $\ldots \ldots \ldots \ldots \ldots \ldots \ldots \ldots \ldots \ldots 1$ 2 $24 \ldots \ldots \ldots$

e. e-Marketplace $\ldots \ldots \ldots \ldots \ldots \ldots \ldots \ldots \ldots \ldots 1 \quad 2 \quad 3 \quad 4 \quad 5$

Benefits Derived at Work (Please tick $\sqrt{ }$ the appropriate box.):

a. Information standardisation

Yes

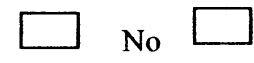

b. One-Stop Submission

Yes

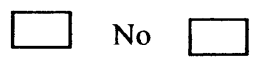

c. Electronic Buildable Design Appraisal System (eBDAS)

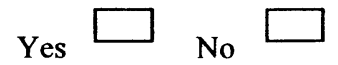

d. e-Collaboration

Yes

No 


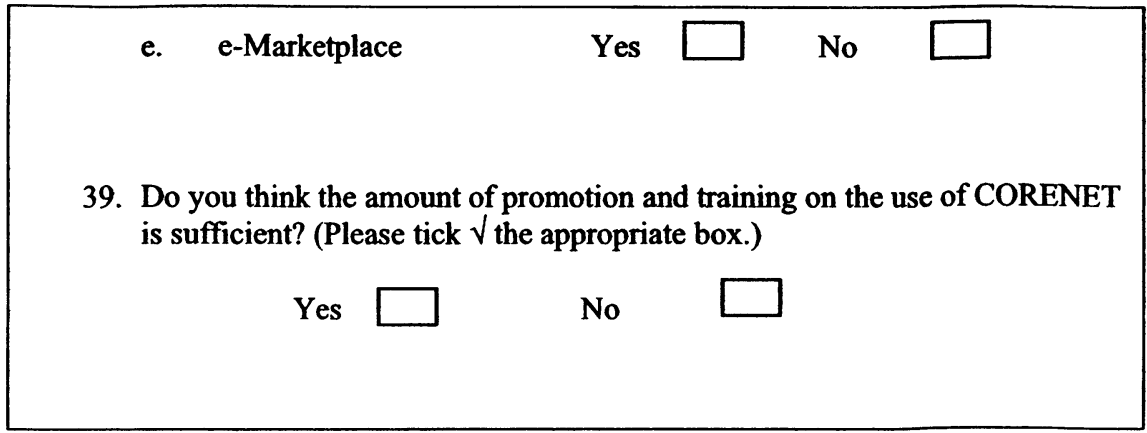

(Note: The IBP/IBS project was only completed after the survey.)

Figure 2. Questions Relating to the CORENET Projects

On the infrastructure projects, namely OSSC and eBDAS, a majority of the respondents had selected the neutral option ' 3 ', that is, neither too slow nor too fast for the speed of implementation. And, the percentages obtained are $50.7 \%$ for OSSC and $55.0 \%$ for eBDAS. For respondents who had indicated that it was too slow, the percentages are $9.0 \%$ for OSSC and $8.3 \%$ for eBDAS. While for too fast, they are $19.4 \%$ for OSSC and $16.7 \%$ for eBDAS.

The majority of respondents had indicated 'Yes' for benefits derived at work from the OSSC $(77.1 \%)$ and eBDAS $(53.2 \%)$. The respective percentages had given a general indication of the level of adoption as well as extent of successful implementation of the two projects.

On promotion and training, there were a higher percentage of respondents who had indicated 'No' $(64.9 \%)$ on whether the amount provided by the BCA was sufficient. There were $35.1 \%$ who responded 'Yes'. The results had given a strong signal for the need to increase promotional and training activities so as to achieve higher adoption of the projects by the industry.

\section{DISCUSSION OF FINDINGS}

While the response percentages for benefits derived at work from using the OSSC and eBDAS had been found to be the majority, $77.1 \%$ and $53.2 \%$, respectively, it was appropriate to note that only $11.1 \%$ of the 754 targeted companies (or 84 companies) had responded to the survey. Hence, it could be implied that there would have been many more companies that had either not used these systems or not derived benefits from them.

A vital prerequisite for companies to use the Government to Business infrastructure is the adoption of a set of national IT standards upon which the platforms are based. In Singapore, the Singapore Standard Code of Practice for Construction Computer-Aided Design (SS CP83: 2000; 2004) [2] come in parts - Part 1: Organisation and naming of CAD layers; Part 2: CAD symbols; Part 3: Organising and naming of CAD files; Part 4: CAD drafting conventions; and Part 5: Colour and 
line-type. Together, they provide a set of standards to enable architectural companies to prepare CAD drawings for electronic transmission (or submission) of their applications to the OSSC. Based on the same survey, the results had indicated that adoption of the SS CP83 by the industry had been moderately low. Only $38.8 \%$ of the respondents had indicated they use the standard.

Hence, to begin with, a way forward to helping to increase the use of the Government to Business infrastructure is for the BCA to promote the SS CP83 together with the completed projects such as the OSSC, eBDAS and IBP/IBS. With reference to the survey results, a majority of the respondents $(64.9 \%)$ had indeed indicated that promotional and training activities had been insufficient and, therefore, this aspect could be improved upon.

\section{GENERAL CONCLUSIONS}

Government policies are crucial in mapping the vision and setting the directions for large-scale change as evident in the area of IT. As a case in point, a very active government policy to reduce the administrative burden on companies had worked well for Denmark, winning her the title of the world's web-savviest nation in 2004 [3]. She has put in place a government portal that integrates five ministries and 24 other organisations where companies can access a broad range of services.

From the company's viewpoint, innovation through continuous improvement ensures that business and operational processes are constantly aligned with prevailing practice. And, the goal is to satisfy changing customer demand and expectations within the country and even beyond. Hence, process re-engineering is vital in ensuring that practices stay current and enterprises remain relevant in a globalising business environment. In the course of standardisation, the basic value is derived from the need to re-engineer some aspects of the existing process and consider new approaches to arriving at an improved process. In other words, challenging generally accepted practices and established strategies would bring about process innovation and improvement. By standardising practices, it will also mean businesses could offer a quicker and higher quality service through, possibly, using IT to become more efficient and customer centric [4].

\section{ACKNOWLEDGEMENTS}

The Singapore IT Barometer 2003 Survey was wholly funded by the National University of Singapore.

\section{REFERENCES}

1. M. Hammer and J. Champy, Reengineering the Corporation: A Manifesto for Business Revolution (HarperBusiness: USA, 2001). 


\section{Bee-Hua Goh}

2. Singapore Standard, Code of Practice for Construction Computer-Aided Design (CAD), CP 83: Part 1, 2, 3, 4, 5 (Spring: Singapore, 2000, 2004).

3. The Straits Times, Danes the Web-savviest (Singapore Press Holdings: Singapore, 20 April 2004).

4. B.H. Goh, Towards iN2015 - Implications for the Construction Industry on its Future Standardisation and ICT Programmes, Synthesis Journal 2006, Information Technology Standards Committee, Standards, Productivity and Innovation Board (SPRING Singapore, 2006), pp.125-138.

5. Building and Construction Authority (BCA). http://www.bca.gov.sg.

6. Construction and Real Estate Network (CORENET). http://www.corenet.gov.sg. 